\title{
Prolonged PEG-IFN and RBV Is Effective in Patients with HCV Genotype 1 and High Viral Load Who Achieved Virological Response Later than 24 Weeks
}

\author{
Taisuke Ueda Hobyung Chung Masatoshi Kudo Emi Ishikawa \\ Sousuke Hayaishi Chie Tatsumi Tatsuo Inoue Norihisa Yada Satoru Hagiwara \\ Yasunori Minami Kazuomi Ueshima \\ Department of Gastroenterology and Hepatology, Kinki University School of Medicine, Osaka-Sayama, Japan
}

\section{Key Words}

Genotype $1 \cdot$ Hepatitis C virus $\cdot$ High viral load .

Late virological responder • Peginterferon · Ribavirin •

Sustained virological response

\begin{abstract}
Objective: The extension of treatment duration has been proposed in late virological responders with hepatitis $C$ virus (HCV) genotype 1 and high viral load. However, the effectiveness of extended treatment in patients whose serum HCV RNA become undetectable later than 24 weeks of treatment (ultra-late virological responder; ULVR) has not yet been determined. Methods: A total of 130 patients infected with HCV genotype 1 and who had high viral load were treated with pegylated interferon (PEG-IFN) and ribavirin (RBV) combination therapy. We retrospectively analyzed 10 ULVR who received extended combination treatment beyond 48 weeks. Results: The duration of the combination treatment for ULVR ranged between 59 and 119 weeks, and the mean duration was 80 weeks. Although the majority of ULVR were older female patients ( $\geq 60$ years) with factors related to poor therapeutic response, 8 patients (80\%) achieved sus-
\end{abstract}

tained virological response (SVR). The SVR rate correlated well with the duration of the treatment. Five ULVR achieved SVR when treatment was continued until serum HCV RNA remained undetectable for longer than 48 weeks. Conclusion: The extended duration of PEG-IFN and RBV combination treatment is a possible strategy to improve treatment response in HCV genotype 1 infection, even for ULVR.

Copyright $\odot 2010$ S. Karger AG, Basel

\section{Introduction}

Peginterferon (PEG-IFN) and ribavirin (RBV) combination treatment is the standard treatment for chronic hepatitis $\mathrm{C}$ infection that results in improved sustained virological response (SVR), even in patients with hepatitis $\mathrm{C}$ virus (HCV) genotype 1 and high viral load $[1,2]$. Recently, an extension of the treatment duration to 72 weeks has been proposed for late virological responders who have a 2-log decrement in HCV RNA from baseline at 12 weeks of the treatment and undetectable serum HCV RNA after 13-24 weeks of the treatment [3, 4]. However, the benefit of the extended combination treat-

\section{KARGER}

Fax +4161306 1234 E-Mail karger@karger.ch www.karger.com
(C) 2010 S. Karger AG, Basel

0300-5526/10/0531-0055\$26.00/0

Accessible online at:

www.karger.com/int
Masatoshi Kudo, MD, PhD

Department of Gastroenterology and Hepatology

Kinki University School of Medicine

377-2 Ohno-Higashi, Osaka-Sayama, Osaka 589-8511 (Japan)

Tel. +81 72366 0221, Fax +81 72367 2880, E-Mail m-kudo@ med.kindai.ac.jp 
ment in patients whose serum HCV RNA become undetectable later than 24 weeks of the treatment (ultra-late virological responder; ULVR) has not yet been determined.

In the present study, we addressed the effectiveness and feasible duration of the extended PEG-IFN and RBV combination treatment in ULVR infected with HCV genotype 1 and who had a high viral load.

\section{Patients and Methods}

A total of 130 patients infected with HCV genotype 1 and who had a high viral load were treated with PEG-IFN $\alpha-2 b$ (PegIntron; Schering-Plough, Kenilworth, N.J., USA) and RBV (Rebetol; Schering-Plough) combination treatment between January 2005 and August 2008 at the Kinki University Hospital. PEG-IFN $\alpha$-2b was administered at $1.5 \mu \mathrm{g} / \mathrm{kg}$ subcutaneously each week and RBV was administered orally at a dose of $600 \mathrm{mg}$ to patients weighing $<60 \mathrm{~kg}, 800 \mathrm{mg}$ to those weighing $60-80 \mathrm{~kg}$, and $1,000 \mathrm{mg}$ to those weighing $\geq 80 \mathrm{~kg}$ daily. The dose reduction and discontinuation of the combination treatment was determined according to standard protocols. The total duration of the treatment was determined by the attending physicians or by patient request. The serum HCV RNA was measured before commencement of treatment and every month during the treatment by quantitative Amplicor HCV monitor assay (version 2.0, Roche Diagnostics; detection limit $500 \mathrm{IU} / \mathrm{ml}$ ). When the quantitative assay showed undetectable levels of HCV RNA, a qualitative Amplicor HCV assay (version 2.0, Roche Diagnostics; detection limit $50 \mathrm{IU} / \mathrm{ml}$ ) was applied. We defined patients that had undetectable HCV RNA at later than 24 weeks of treatment as ULVR.

Patient characteristics assessed at baseline included age, sex, body mass index (BMI), histological results of pre-treatment liver biopsy (Metavir scoring: F0 = no fibrosis; F1 = portal fibrosis; F2 = few septa; F3 = many septa without cirrhosis; F4 = cirrhosis), platelet count, serum HCV RNA before treatment, viral amino acid (aa) substitutions, and 2-log decrement in serum HCV RNA from baseline at 12 and 24 weeks of the treatment. Viral aa substitutions were determined for the IFN sensitivity-determining region (ISDR) in the HCV NS5A and substitutions at positions 70 and 91 in the HCV core region, as previously described [5-7]. The ISDR was defined as wild type when there were 1 or no aa substitutions, and defined as mutant type when there were 2 or more.

\section{Results}

\section{Overall Response in Patients with HCV Genotype 1 and High Viral Load}

The SVR rate for combination treatment in all the patients with genotype 1 and high viral load was $41.5 \%$ (54/130) by intention-to-treat analysis, and 54.3\% (51/94) by per-protocol-study analysis.

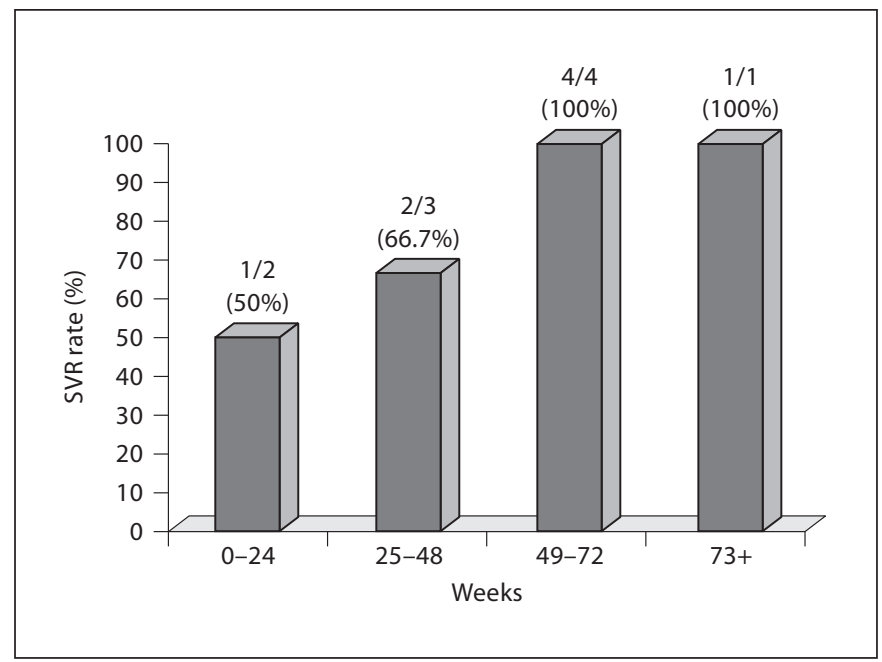

Fig. 1. The duration of maintaining undetectable HCV RNA while undergoing PEG-IFN/RBV combination treatment (maintenance treatment) was correlated with SVR rate. The horizontal axis represents the duration between the time serum HCV RNA was undetectable and the termination of the treatment.

\section{Efficacy and Side Effects of Extended Treatment in ULVR}

Among 10 ULVR, 8 patients achieved SVR by the extended treatment. The characteristics for ULVR are shown in table 1 . Eight patients $(80 \%)$ were older than 60 years of age and $7(70 \%)$ were female. Four of the 8 patients with SVR showed severe fibrosis (F3) or cirrhosis (F4). Among 5 patients with SVR who were assessed for aa substitutions in HCV RNA, 3 patients showed a mutant type at ISDR and 4 showed wild type at both aa 70 and aa 91 in the HCV core region, while 2 patients with non-SVR showed substitutions at either aa 70 or aa 91 . Six of $10(60 \%)$ ULVR patients achieved a 2-log decrement of serum HCV RNA from baseline at 12 weeks and 8 patients $(80 \%)$ at 24 weeks. Eight patients (80\%) had undetectable HCV RNA within 36 weeks of treatment and the remaining 2 patients (1 each of the non-SVR and SVR groups) had undetectable HCV RNA at 48 and 60 weeks, respectively. The total duration of the combination treatment ranged from 59 to 119 weeks, with a mean duration of 80 weeks. All patients with SVR received extended treatment beyond 72 weeks with the exception of 1 patient, while treatment was stopped before 72 weeks for 2 patients with non-SVR.

Figure 1 shows the SVR rates according to the duration of maintaining undetectable serum HCV RNA while undergoing treatment (maintenance treatment). The SVR 
Fig. 2. Outcomes of the extended combination treatment in 22 patients who had detectable HCV RNA at 24 weeks of treatment. wks $=$ Weeks.

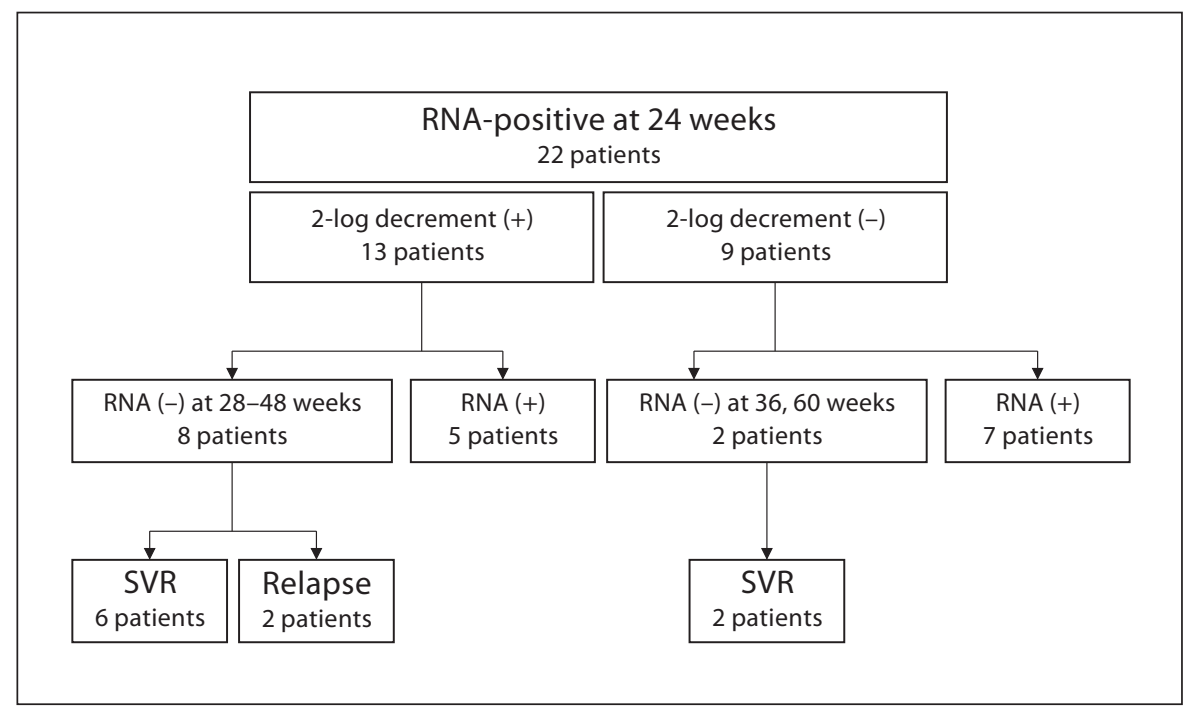

Table 1. Patient characteristics of ULVR

\begin{tabular}{|c|c|c|c|c|c|c|c|c|c|c|c|c|c|c|}
\hline \multirow[t]{2}{*}{$\begin{array}{l}\text { Case } \\
\text { No. }\end{array}$} & \multirow[t]{2}{*}{$\begin{array}{l}\text { Age } \\
\text { years }\end{array}$} & \multirow[t]{2}{*}{$\begin{array}{l}\text { Gen- } \\
\text { der }\end{array}$} & \multirow[t]{2}{*}{ BMI } & \multirow[t]{2}{*}{$\begin{array}{l}\text { F } \\
\text { stage }\end{array}$} & \multirow{2}{*}{$\begin{array}{l}\text { Platelet } \\
\text { count/ } \\
\mu l\end{array}$} & \multirow[t]{2}{*}{$\begin{array}{l}\mathrm{HCV} \text { RNA } \\
\mathrm{KIU} / \mathrm{ml}\end{array}$} & \multirow[t]{2}{*}{ ISDR } & \multicolumn{2}{|c|}{$\begin{array}{l}\text { HCV core } \\
\text { mutation }\end{array}$} & \multicolumn{2}{|c|}{$\begin{array}{l}\text { HCV RNA 2-log } \\
\text { decrease }\end{array}$} & \multirow{2}{*}{$\begin{array}{l}\text { RNA } \\
\text { negative } \\
\text { weeks }\end{array}$} & \multirow{2}{*}{$\begin{array}{l}\text { Total } \\
\text { treatment } \\
\text { duration } \\
\text { weeks }\end{array}$} & \multirow[t]{2}{*}{ SVR } \\
\hline & & & & & & & & aa 70 & aa 91 & 12 weeks & 24 weeks & & & \\
\hline 1 & 56 & $\mathrm{~F}$ & 22.5 & 2 & 16.2 & 975 & $\mathrm{M}$ & $\mathrm{W}$ & $\mathrm{W}$ & yes & yes & 28 & 77 & yes \\
\hline 2 & 64 & $\mathrm{~F}$ & 26.7 & 3 & 18.9 & 2,400 & W & W & $\mathrm{W}$ & yes & yes & 28 & 83 & yes \\
\hline 3 & 71 & $\mathrm{~F}$ & 18.5 & 1 & 9.9 & 1,380 & $\mathrm{M}$ & $\mathrm{W}$ & $\mathrm{W}$ & yes & yes & 28 & 83 & yes \\
\hline 4 & 77 & $\mathrm{M}$ & 23.7 & 4 & 7.8 & 166 & ND & ND & ND & yes & yes & 32 & 59 & yes \\
\hline 5 & 62 & $\mathrm{~F}$ & 19.6 & 1 & 23.6 & 252 & $\mathrm{M}$ & $\mathrm{W}$ & $\mathrm{W}$ & - & yes & 32 & 85 & yes \\
\hline 6 & 63 & $\mathrm{~F}$ & 19.9 & 3 & 8.9 & 895 & ND & ND & ND & - & yes & 32 & 119 & yes \\
\hline 7 & 65 & $\mathrm{~F}$ & 21.2 & 1 & 23.2 & 445 & $\mathrm{~W}$ & $\mathrm{M}$ & $\mathrm{W}$ & - & - & 26 & 82 & yes \\
\hline 8 & 60 & $\mathrm{~F}$ & 22.1 & 3 & 13.6 & 1,350 & ND & ND & ND & - & - & 60 & 81 & yes \\
\hline 9 & 73 & $\mathrm{M}$ & 20.2 & 1 & 8.2 & 943 & $\mathrm{M}$ & $\mathrm{M}$ & $\mathrm{W}$ & yes & yes & 48 & 62 & - \\
\hline 10 & 64 & $\mathrm{M}$ & 26.6 & 1 & 16.8 & 1,750 & W & W & $\mathrm{M}$ & yes & yes & 32 & 68 & - \\
\hline
\end{tabular}

$\mathrm{M}=$ mutant type; $\mathrm{W}=$ wild type $\mathrm{ND}=$ not determined.

rate correlated well with the duration of the maintenance treatment. All 5 ULVR achieved SVR when maintenance treatment was continued for longer than 48 weeks.

The PEG-IFN dose was reduced in 4 of 10 (40\%) ULVR within 8 weeks of the treatment, and RBV dose was reduced in 3 of 10 ULVR within 28 weeks of the treatment. Dose reduction of both PEG-IFN and RBV was required for 2 patients. Dose reduction was not required during the extended treatment duration and none of the treatments were terminated because of side effects.

\section{Response to the Extended Treatment in Patients with}

Detectable HCV RNA at 24 Weeks

The outcomes of the extended combination treatment for 22 patients, including 10 ULVR, who had detectable HCV RNA at 24 weeks, are shown in figure 2. Among 13 patients who achieved a 2-log decrement in serum HCV RNA at 24 weeks, eight patients achieved undetectable HCV RNA between 28 and 48 weeks, including 6 with SVR. Five patients remained positive for serum $\mathrm{HCV}$ RNA despite extended treatment for 55-105 weeks with a mean duration of 88 weeks. Even in 9 patients who did not achieve a 2-log decrement in HCV RNA at 24 weeks, 
2 patients (22\%) achieved SVR as a result of extended treatment beyond 72 weeks, while the remaining 7 patients did not.

\section{Discussion}

For the treatment of patients infected with HCV genotype 1 and who have high viral load, a 72-week course of PEG-IFN and RBV treatment has become a standard treatment regimen for late virological responders $[3,4]$. However, the benefit of extended treatment in patients who had undetectable serum HCV RNA later than 24 weeks of the treatment remains to be elucidated. In the present study, the extended combination treatment attained 80\% (8/10) SVR in ULVR and 46\% (6/13) SVR in patients who achieved 2-log decrement in HCV RNA from baseline at 24 weeks but still had detectable HCV RNA. Furthermore, here we describe 2 cases with SVR that failed to achieve a $2-\log$ decrement in serum $\mathrm{HCV}$ RNA from baseline at 24 weeks.

Several host and viral factors contribute to SVR in PEG-IFN and RBV combination treatment for Japanese patients infected with HCV genotype 1 and who have high viral load. The host factors include younger age, male gender, mild liver fibrosis, platelet count, LDL cholesterol values and $\gamma$-glutamyl transpeptidase values. The viral factors include aa substitutions in the ISDR of HCV NS5A and aa substitutions in the HCV core region [5-9]. In addition, the total dose of PEG-IFN or RBV is another important factor that can affect the treatment outcome $[8,9]$. In the present study, most ULVR were difficult-to-treat patients with respect to host factors, 8 patients $(80 \%)$ were older than 60 years of age and 7 patients (70\%) were female. Furthermore, 4 of 8 patients with SVR (50\%) showed severe fibrosis (F3) or cirrhosis (F4) which is another well-known refractory factor to IFN treatment. These patient characteristics were significantly different from those of patients who achieved early virological response, having undetectable HCV RNA within 12 weeks of the treatment (data not shown). On the other hand, ULVR with SVR had positive viral factors regarding the aa substitutions in the ISDR and HCV core regions. Although we cannot exclude the possibility that these viral factors contributed to SVR rate even in ULVR, an extended combination treatment regimen is still considered a feasible treatment strategy for ULVR.

There are several limitations to this study. First, the Amplicor HCV assay method was used to measure serum HCV RNA in this study. The results presented here are likely to be different if patients were monitored by TaqMan qPCR, a state-of-the-art method with higher sensitivity. Second, this study is retrospective and the duration and dose of the treatment varied considerably. Further prospective studies are necessary to confirm an optimal treatment regimen for ULVR.

In conclusion, the extended duration of PEG-IFN and RBV combination treatment is beneficial in terms of virological response, even for ULVR. The extension of the treatment does not seem to increase side effects or the rate of dose reductions, and treatment should be continued until the serum HCV RNA remains undetectable for at least 24 weeks and, if possible, for longer than 48 weeks during the course of treatment.

\section{Disclosure Statement}

The authors declare that they have no financial conflict of interest.

\section{References}

1 Manns MP, McHutchinson JG, Gordon SC, Rustgi VK, Shiffman M, Reindollar R, Goodman ZD, Koury K, Ling M, Albrecht JK: Peginterferon alfa- $2 \mathrm{~b}$ plus ribavirin compared with interferon alfa- $2 b$ plus ribavirin for initial treatment of chronic hepatitis C: a randomized trial. Lancet 2001;358:958-965.

-2 Fried MW, Shiffman ML, Reddy KR, Smith C, Marinos G, Goncales FL Jr, Haussinger D, Diago M, Carosi G, Dhumeaux D, Craxi A, Lin A, Hoffman J, Yu J: Peginterferon alfa-2a plus ribavirin for chronic hepatitis $\mathrm{C}$ virus infection. N Engl J Med 2002;347:975-982.
>3 Berg T, von Wagner M, Nasser S, Sarrazin C, Heintges T, Gerlach T, Buggisch P, Goeser T, Rasenack J, Page GR, Schmidt WE, Kallinowski B, Klinker H, Spengler U, Martus P, Alshuth U, Zeuzem S: Extended treatment duration for hepatitis $\mathrm{C}$ virus type 1: comparing 48 versus 72 weeks of peginterferonalfa-2a plus ribavirin. Gastroenterology 2006;130:1086-1097.

4 Pearlman BL, Ehleben C, Saifee S: Treatment extension to 72 weeks of peginterferon and ribavirin in hepatitis $\mathrm{C}$ genotype 1-infected slow responders. Hepatology 2007;46:16881694. 
5 Enomoto N, Sakuma I, Asahina Y, Kurosaki M, Murakami T, Yamamoto C, Izumi N, Marumo F, Sato C: Comparison of fulllength sequences of interferon-sensitive and resistant hepatitis $\mathrm{C}$ virus $1 \mathrm{~b}$. Sensitivity to interferon is conferred by amino acid substitutions in the NS5A region. J Clin Invest 1995;96:224-230.

-6 Enomoto N, Sakuma I, Asahina Y, Kurosaki M, Murakami T, Yamamoto C, Ogura Y, Izumi N, Marumo F, Sato C: Mutations in the nonstructural protein $5 \mathrm{~A}$ gene and response to interferon in patients with chronic hepatitis C virus 1b infection. N Engl J Med 1996; 334:77-81.
7 Akuta N, Suzuki F, Sezaki H, Suzuki Y, Hosaka T, Someya T, Kobayashi M, Saitoh S, Watahiki S, Sato J, Matsuda M, Kobayashi M, Arase Y, Ikeda K, Kumada H: Association of amino acid substitution pattern in core protein of hepatitis $C$ virus genotype $1 \mathrm{~b}$ high viral load and non-virological response to interferon-ribavirin combination therapy. Intervirology 2005;48:372-380.
8 Akuta N, Suzuki F, Kawamura Y, Yatsuji H, Sezaki H, Suzuki Y, Hosaka T, Kobayashi M, Kobayashi M, Arase Y, Ikeda K, Kumada H: Predictive factors of early and sustained responses to peginterferon plus ribavirin combination therapy in Japanese patients infected with hepatitis $C$ virus genotype $1 \mathrm{~b}$ : amino acid substitutions in the core region and lowdensity lipoprotein cholesterol levels. J Hepatol 2007;46:403-410.

-9 Okanoue T, Itoh Y, Hashimoto H, Yasui K, Minami M, Takehara T, Tanaka E, Onji M, Toyoda J, Chayama K, Yoshioka K, Izumi N, Akuta N, Kumada H: Predictive values of amino acid sequences of the core and NS5A regions in antiviral therapy for hepatitis $\mathrm{C}$ : a Japanese multi-center study. J Gastroenterol 2009;44:952-963. 